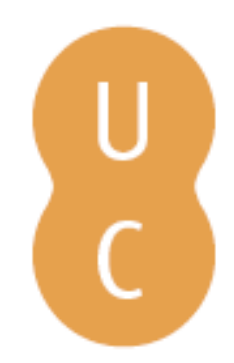

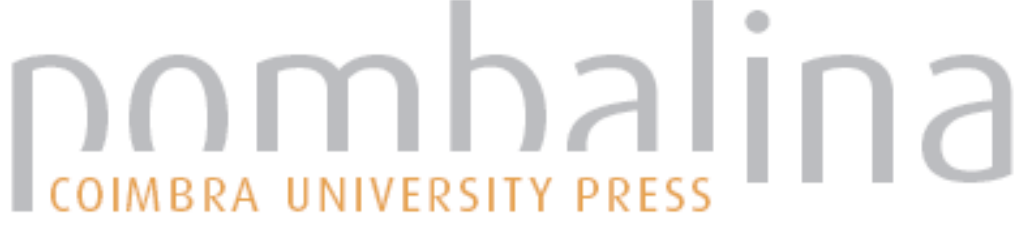

\section{The role of future time perspective in career decision making}

Autor(es): $\quad$ Walker, Terrance L.; Tracey, Terence J. G.

Publicado por: Imprensa da Universidade de Coimbra

URL

persistente: URI:http://hdl.handle.net/10316.2/38622

DOI: $\quad$ DOI:http://dx.doi.org/10.14195/978-989-26-0775-7_18

Accessed : $\quad$ 26-Apr-2023 11:32:30

A navegação consulta e descarregamento dos títulos inseridos nas Bibliotecas Digitais UC Digitalis, UC Pombalina e UC Impactum, pressupõem a aceitação plena e sem reservas dos Termos e Condições de Uso destas Bibliotecas Digitais, disponíveis em https://digitalis.uc.pt/pt-pt/termos.

Conforme exposto nos referidos Termos e Condições de Uso, o descarregamento de títulos de acesso restrito requer uma licença válida de autorização devendo o utilizador aceder ao(s) documento(s) a partir de um endereço de IP da instituição detentora da supramencionada licença.

Ao utilizador é apenas permitido o descarregamento para uso pessoal, pelo que o emprego do(s) título(s) descarregado(s) para outro fim, designadamente comercial, carece de autorização do respetivo autor ou editor da obra.

Na medida em que todas as obras da UC Digitalis se encontram protegidas pelo Código do Direito de Autor e Direitos Conexos e demais legislação aplicável, toda a cópia, parcial ou total, deste documento, nos casos em que é legalmente admitida, deverá conter ou fazer-se acompanhar por este aviso. 


\section{INTERNATIONAL \\ STUDIES IN TIME \\ PERSPECTIVE}

MARIA PAULA PAIXÃO

JOSÉ TOMÁS DA SILVA

(COORD.)

VICTOR ORTUÑO

PEDRO CORDEIRO

(EDITORS)

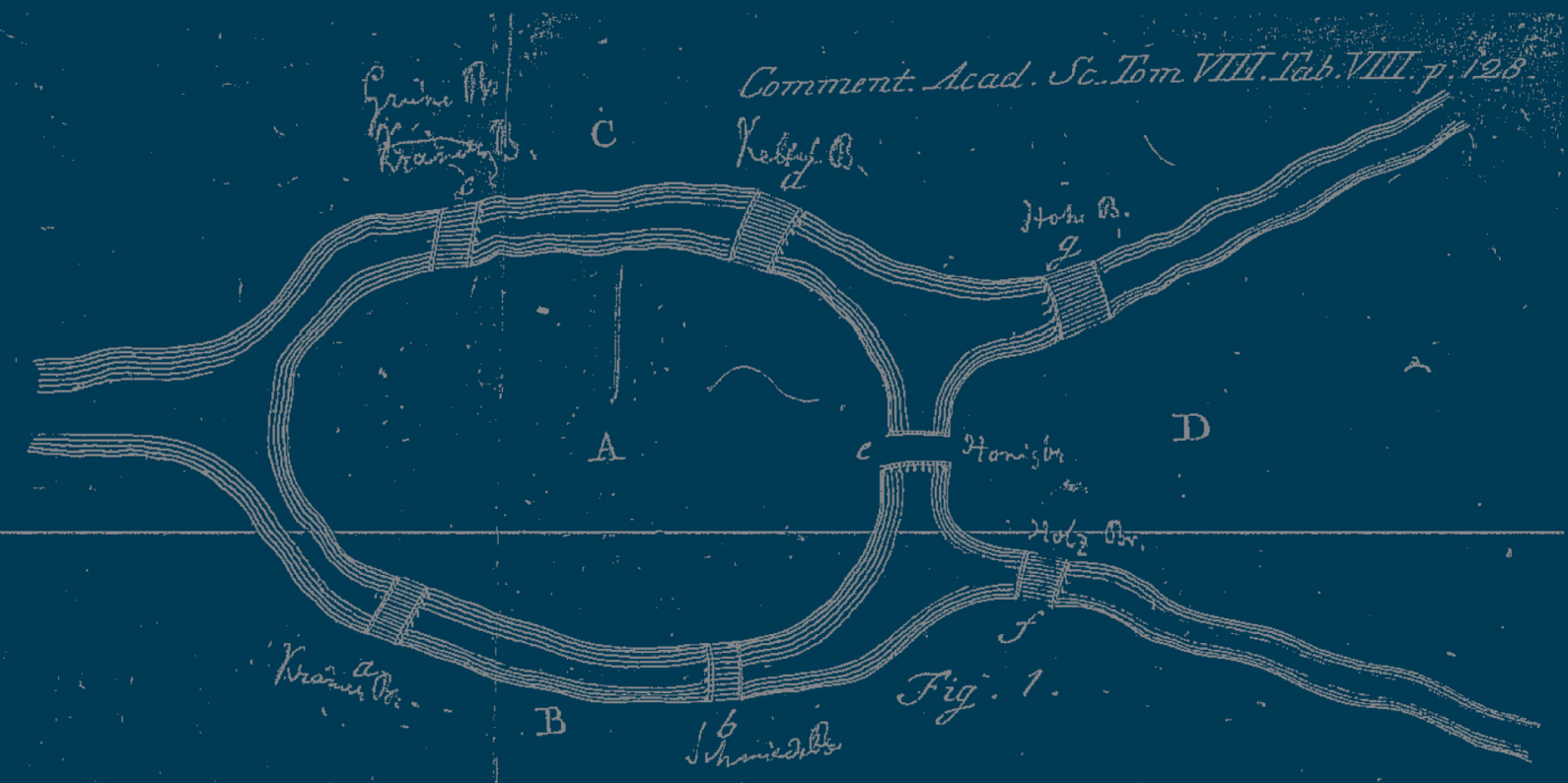

IMPRENSA DA

UNIVERSIDADE

DE COIMBRA

COIMBRA

UNIVERSITY

PRESS 
Chapter 18

THE ROLE OF FUTURE TIME PERSPECTIVE IN CAREER DECISION MAKING

\author{
Terrance L. Walker \\ Terence J. G. Tracey \\ Arizona State University, USA
}

\begin{abstract}
Aвstract: The present study of two hundred and seven university students examined the structural relation of future-orientation (both valence and instrumentality), career decision-making self-efficacy and career indecision (choice/commitment anxiety and lack of readiness) in a sample of 218 college students. Future time perspective was viewed as a key input to career decision making. Structural equation modeling results indicated that valence was not significantly related to career decision-making self-efficacy, choice/commitment anxiety and lack of readiness. However, instrumentality completely mediated the relation between valence and career decision-making self-efficacy, choice/commitment anxiety and lack of readiness. Instrumentality was significantly related to career decision-making selfefficacy and lack of readiness. Career decision-making self-efficacy completely mediated the relation between instrumentality and choice/commitment anxiety; however, it only partially mediated the relation between instrumentality and lack of readiness. Although the proposed model was invariant across gender, the findings indicated that women reported higher instrumentality and lower lack of readiness than did men. No differences were found for career decision-making self-efficacy and choice/commitment anxiety across gender. The findings suggest that psychologists, counselors, and teachers should consider the role future time perspective in university students' career development.
\end{abstract}

Keywords: future time perspective, valence, instrumentality, career decision-making self-efficacy, career indecision.

\title{
INTRODUTION
}

Time perspective has been defined as an individual's ability to move into the past through the use of memory and/or to imagine the future (Savickas, 1991). Future time perspective, in particular, has been conceptually understood as the individuals' mental representation of the future. Two important aspects of future time perspective that have been found to be of particular relevance are valence and perceived Instrumentality. Valence has been described as the importance individuals attribute or place on goals that can attained in the future. According to De Volder and Lens (1982), present tasks or responsibilities students have are also important components of future time perspective because they lead directly to future goals. These present-oriented tasks are conceptualized as having perceived instrumentality.

Super (1980) first introduced his concept of planfulness. Savickas, Silling \& Schwartz (1984) also indicated that future orientation and planning attitudes relate to career choice readiness. Similar to Super and Savickas and colleagues, we proposed that the orientation and continuity components of future time perspective will be associated with career 
decision-making. Career decision self-efficacy is defined as having confidence to make decisions based upon one's self-concept, goals, and career options. The career decision process can be difficult and career indecision can result (Brown et al., 2012). Crites (1978) and Savickas, Silling and Schwartz (1984) posit that people's inability to think in terms of time perspective - unable to look beyond immediate tasks and obstacles- is a good indicator of level of career indecision.

Brown et al. (2012) have demonstrated that career indecision is not a unidimensional construct. They demonstrated that there are four relatively independent dimensions of career indecision but we thought that only the choice/commitment anxiety and lack of readiness dimensions were the most appropriate criteria of career indecision relative to future time perspective. The former describes one's inability to commit to a decision to due to having a multiplicity of available options or to not having a sufficient amount of information that would permit one to make a confident decision, and the latter is refers to a genuine lack of planfulness and goal directedness. As such, we hypothesized that individuals who understand the importance of future goals and present-task behaviors would experience less anxiety about the career choices, and would also be better prepared to make informed decisions. (See Figure 1 for complete model).

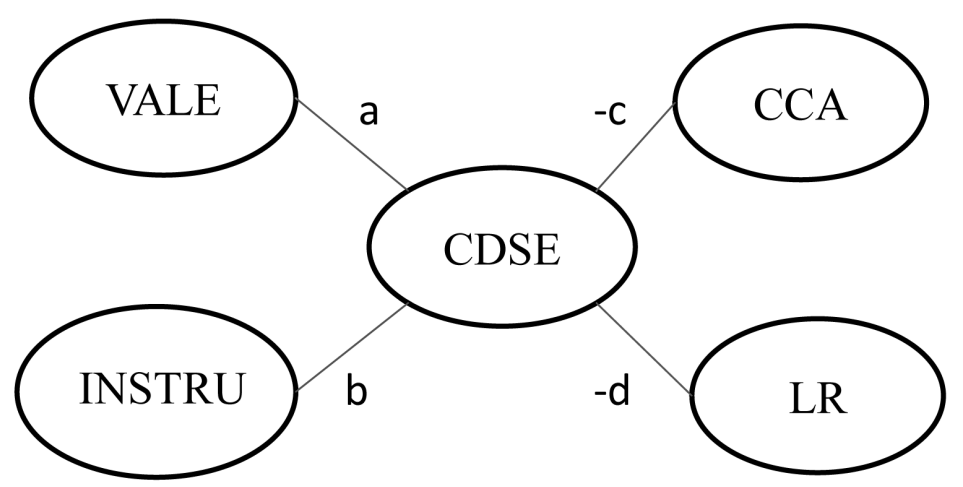

Figure1. Presentation of hypothesized model of relations between (VALE) and instrumentality (INSTRU), and career decision-making self-efficacy (CDSE) and choice/commitment anxiety (CCA) and lack of readiness (LR). (-) Signifies an inverse relation between the variables.

\section{Method}

\section{Participants}

The sample was comprised of 218 university students enrolled at Arizona State University. Of the total sample, $107(49 \%)$ were women (mean age 19.55, SD=1.40) and $111(51 \%)$ were men (mean age 19.70, SD=2.10). There were $136(62.4 \%)$ White, 37 (17\%) Hispanic, 15 (6.9\%) African American, 13 (6\%) Asian American/Pacific Islander, and 17 (7.8\%) Multi-racial students. There were 59 (27.1\%) Freshmen, 61 (28\%) Sophomores, 67 (30.7\%) Juniors, and 31 (14.2\%) Seniors. 


\section{Measures}

Sociodemographic. This questionnaire gathered an array of demographic data, which included ethnicity, age, sex, and GPA.

Future Time Perspective (FTS, Shell, 1985; Measure only available in Shell \& Husman, 2001). The FTS assessed the extent to individuals are future-oriented. Valence (7 items) and Instrumentality (12 items) were used as they were the most salient in the present study. For both subscales, participants were asked to indicate their agreement with each question using a 5-point Likert scale from 1 (strongly disagree) to 5 (strongly agree) and responses were summed to yield total subscale scores. In the present study, the internal consistencies for the valence and instrumentality subscales were $\alpha$ 's of .69 and .84 , respectively.

Career Decision Self-Efficacy. The short form of the CDSE scale (Betz, Klein, \& Taylor, 1996) was designed to measure the most important aspect of students' beliefs regarding career decision making. The measure consists of 25 questions and asks students to rate their confidence in their current ability to complete a task. Higher scores indicated more decision-making efficacy. The scale is widely used as a unidimensional test and has been found to be highly reliable and to have sufficient evidence for validity (Betz et al., 1996). Betz et al. (1996) internal reliability coefficients for the total scores of $\alpha=.94$ and .93, respectively. The internal reliability for the current study was .92.

Career Indecision Profile (CIP; Brown et al., 2012). The CIP is a 65-item scale used to assess career indecision. The scale consists of the four subscales with responses rated on a 6-point Likert-type scale ranging from 1 (completely disagree) to 6 (strongly agree). For purposes of the current study, only the choice/commitment anxiety and lack of readiness subscales were used. Higher scores indicated more insecurity and anxiety, and more unpreparedness when making occupational choices. For the current sample, we found internal consistency estimates of $\alpha=.96$ and .92 , for choice/commitment anxiety and lack of readiness respectively.

\section{Procedures}

Data were collected using hardcopy and online forms of the questionnaire that took approximately 15 minutes to complete. The career development class draws individuals from all majors across campus and is one of the most diverse courses with respect to interest distribution. Two hundred and eighteen (87\%) of the 250 students we invited to participate in the study completed the questionnaire. Of the total sample, $161(74 \%)$ of the students completed the survey in class while and 57 (26\%) participants completed the questionnaire online. There was only 5\% (11 people) who did not complete all of the data. Given the low number we used listwise deletion.

\section{Analyses}

Structural equation modeling was used to test both the relational and mediational effects of future time perspective and career decision-making self-efficacy and career indecision (i.e., anxiety/commitment and lack of readiness). Analysis of the proposed model followed the two-step procedure (see Anderson and Gerbing (1988)). 
The maximum-likelihood (ML) estimation method was utilized in order to examine the fit of the model. According to Quintana and Maxwell (1999), the ML procedures are widely used because they are more robust to situations where the distribution departs from normality. To assess for model fit we used several fit indices including the chisquare, comparative fit index (CFI), root-mean-square error of approximation (RMSEA), standardized root-mean-square residual (SRMR) (Hu \& Bentler, 1999). In order to test whether the hypothesized model was superior to other competing models, we followed Hoyle and Panter's (1995) recommendations by performing several comparisons between pairs of tested models with chi-square difference tests. To test the magnitude and significance of mediation effects, we followed Shrout and Bolger's (2002) suggestion to use the bootstrapping procedure.

\section{Results}

Confirmatory factor analysis (CFA) was used to test the measurement model. There were 5 latent factors, each with three or more indicators, in the model (Valence, Instrumentality, Career Decision-Making Self-Efficacy, Choice/Commitment Anxiety, and Lack of Readiness). The fit indices suggest that measurement model reached acceptable fit: $\left(\chi^{2}(110,207)=189.21, p<.01\right.$; CFI $=.96$, RMSEA $=.06$; SRMR $\left.=.05\right)$. Convergent validity was supported for the measures, as factor loading ranged from .41 to .89 , all significant at the $p<.01$ level. (See Table 1 for correlations, means and standard deviations)

The hypothesized model specified in Figure 1 was found to fit the data well with the fit indices reported in Table 2. Each of the fit indices was within acceptable bounds ( $\chi^{2}$ (114, $\mathrm{N}=207)=219.68, p<.01$; CFI $=.95$, RMSEA $=.07$; SRMR $=.07)$, so the hypothesized model was judged to be a good fit to the data.

To examine if our ordering of time perspective leading to career decision making selfefficacy leading to career indecision was appropriate, we examined a viable alternative where career decision making self-efficacy leads to future time perspective which leads to career indecision. The fit indices of this alternate causal model indicated that this model did not fit the data well $\left(\chi^{2}(113, \mathrm{~N}=207)=330.06, p<.01\right.$; CFI $=.88$, RMSEA $=.10$; SRMR $=.15$ ).

To examine if the hypothesized model could be improved we examined the modification indices which indicated that only one parameter should be added to improve the model. The alternative model (ATL 1) was a version of our hypothesized model but with the direct relation between instrumentality and lack of readiness added. ATL 1 was fit to the data and resulted in the following acceptable indices of fit: $\chi^{2}(113,207)=192, p<.01$; $\mathrm{CFI}=.96$; RMSEA $=.07$; SRMR $=.06$. There was a significant difference in chi-square between ALT 1 and HypModel $\left(\chi^{2} \operatorname{diff}(1,207)=27.63, p<.01\right)$, thus indicating ATL 1 to be a superior fit. However, we also wanted to select the model that was most parsimonious, thus removing any regression paths that were not significant. In the modified model (ALT 1a), the regression path from valence to career decision-making self-efficacy was deleted. The model was re-estimated with the paths deleted and resulted in the following acceptable indices: $\chi^{2}(114,207)=192.23, \mathrm{p}<.01 ; \mathrm{CFI}=.96$; RMSEA $=.06$; SRMR $=.06$. There was no significant difference in chi-square between ALT 1 and Alt 1 a $\left(\chi^{2} \operatorname{diff}(1,207)=.23, p<\right.$ $.63)$ thus, we chose the revised model Alt1a as it is the most parsimonious. (See Figure 2) 
Table 1 - Correlations and Coefficient Alphas Among Valence, Instrumentality, Career Decision-Making Self-Efficacy, Choice/Commitment Anxiety and Lack of Readiness ( $n=207)$

\begin{tabular}{|l|r|c|c|c|c|c|}
\hline & 1 & 2 & 3 & 4 & 5 & $\alpha$ \\
\hline Valence & 1.00 & & & & & .69 \\
\hline Instrumentality & $.40^{* *}$ & 1.00 & & & & .84 \\
\hline Career Decision & -.10 & $.28^{* *}$ & 1.00 & & & .92 \\
\hline Choice/Com/Anx & -.12 & $-.20^{* *}$ & -.53 & 1.00 & & .96 \\
\hline Lack of Readiness & $-.16^{*}$ & $-.47^{* *}$ & -.60 & $.35^{* *}$ & 1.00 & .92 \\
\hline$M$ & 23.82 & 51.34 & 95.60 & 80.64 & 29.40 & \\
$S D$ & 4.10 & 6.34 & 13.99 & 27.11 & 10.74 & \\
\hline
\end{tabular}

${ }^{* *} p<.01$

Table 2 - Comparison of Nested, Competing Structural Equation Models for Future Time Perspective $(n=207)$

\begin{tabular}{|l|c|c|c|c|c|c|c|}
\hline Model & $\chi^{2}$ & $d f$ & $p$ & CFI & RMSEA & SRMR & $\chi^{2}$ diff \\
\hline HypModel & 219.68 & 114 & .01 & .95 & .07 & .07 & Alt1-HypModel $=27.68^{* *}$ \\
Alt 1 & 192.00 & 113 & .01 & .96 & .06 & .05 & Alt 1-Alt 1a $=.23$ \\
Alt 1a & 192.23 & 114 & .01 & .96 & .06 & .06 & Alt 1a-HypModel $=27.45^{* *}$ \\
\hline
\end{tabular}

Note. $\chi^{2}=$ chi-square; $\mathrm{CFI}=$ comparative fit index; RMSEA $=$ root-mean-square error of approximation; SRMR $=$ standard root-mean-square residual; $\chi^{2}$ diff $=$ difference in chi-square log likelihood test. A significant chisquare difference tests indicate a significantly worse fit to the data for the model. ${ }^{*} p<.05{ }^{* *} p<.01$

To test the magnitude and significance of mediation effects, we followed Shrout and Bolger's (2002) suggestion to use the bootstrapping procedure. Instrumentality not only directly predicted more CDSE $(.33, p<.01)$, it also predicted less lack of readiness $(-.37$, $p<.01)$, so there was only partial mediation of career decision-making self-efficacy in the instrumentaility and lack of readiness relation $(-.58, p<.01)$. This suggested that the regression path from instrumentality to lack of readiness was reduced in-absolute size but was still different from zero when career decision-making self-efficacy was introduced. Individuals, who endorsed more importance on the relationship between present tasks and future goals, were more likely to be confident in their career decisions and less likely to be unprepared to make career-based decisions. Career decision-making self-efficacy completely mediated the relationship between instrumentality and choice/commitment anxiety $(-.60, p<.01)$.

Thus, our hypothesis that career decision-making self-efficacy would be a significant mediator of the relationship between instrumentality and both choice/commitment anxiety and lack of readiness was supported. Given that valence did not have a path to career decision-making self-efficacy, we tested the mediation of valence through instrumentality for career decision-making self-efficacy, choice/commitment and lack of readiness. Instrumentality completely mediated the relation between valence and career decision- 
making self-efficacy, choice/commitment anxiety and lack of readiness. All of the loadings from the regression paths were significant. (See Figure 2)

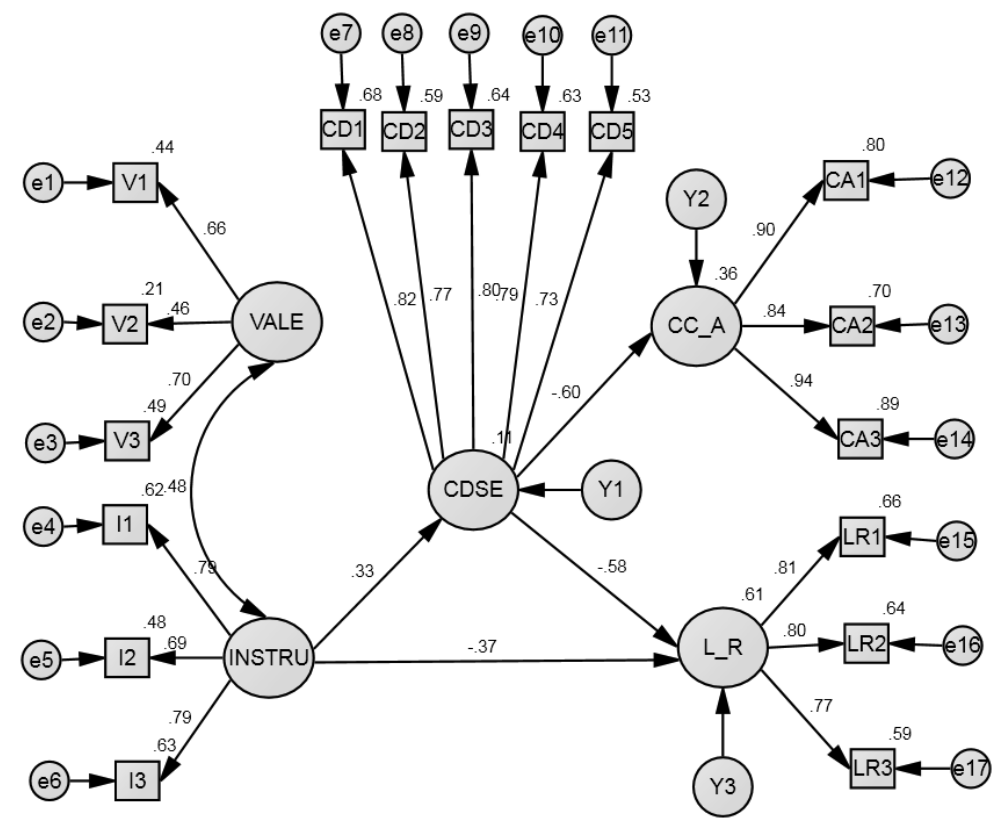

Figure 2. Standardized parameters estimates of the final model (Alt 1a) demonstrates relations between instrumentality (INSTRU), and career decision-making self-efficacy (CSDE), choice/commitment anxiety (CC_A) and lack of readiness (L_R). (-) Signifies an inverse relation between the variables.

\section{Discussion}

The purpose of the study was to test whether the theorized motivational properties of future time perspective could be applied to the career decision making of university students. We hypothesized that individuals' endorsement of valuing the future (valence), while taking requisite steps in order to achieve future goals (instrumentality), would predict higher levels of career decision-making self-efficacy. Career decision-making self-efficacy was expected to mediate the relationship between valence and instrumentality and choice/ commitment anxiety and lack of readiness). Results of this study provide adequate support for our proposed structural model and proved to be superior to the alternative model in which career decision-making self-efficacy was the primary predicting variable. However, its generalizability is somewhat limited because this sample consisted of predominately White (62.4\%) students. Second, although structural equation methods were used to test "causal" models, the data collected were cross-sectional and, thus, cannot provide evidence of actual causation. Finally, in this study, only two subscales were used to represent future time perspective which might limit the degree to which the construct of future time perspective is captured. 
Ongoing research in this area could help improve interventions geared towards individuals seeking vocational guidance. While we recognize that these results pertain only to the relations among the variables in the current study, they may have some implications for how interventions can be designed.

\section{REFERENCES}

Anderson, J. C., \& Gerbing, D. W. (1988). Structural equation modeling in practice: A review and recommended two-step approach. Psychological Bulletin, 103 (3), 411-423. doi: 10.1037//00332909.103.3.411

Betz, N. E., Klein, K. L., \& TAYlor, K. M. (1996). Evaluation of a short form of the career decisionmaking self-efficacy scale. Journal of Career Assessment, 4, 47-57. doi:10.1177/106907279600 400103

Brown, S. D., Hacker, J., Abrams, M., Carr, A., Rector, C., Lamp, K., \& Siene, A. (2012). Validation and measurement of a four factor model of career indecision. Journal of Career Assessment, 20(1), 3-21. doi:10.1177/10672711417154

Crites, J. O. (1978). Theory and research handbook for the Career Maturity Inventory. Monterey, CA: CTB/McGraw-Hill.

DeVolder, M. L., \& Lens, W. (1982). Academic achievement and future time perspective as a cognitive-motivational concept. Journal of Personality \& Social Psychology, 42, 566-571. doi:10.1037/0022-3514.42.3.566

Hoyle, R. H., \& Panter, A. T. (1995). Writing about structural equation models. In R.H. Hoyle (Ed.), Structural equation modeling: Concepts, issues, and applications (pp. 158-176). Thousand Oaks, CA: Sage Publications.

Hu, L., \& Bentler, P. M. (1999). Cutoff criteria for fit indexes in covariance structure analysis: Conventional criteria versus new alternatives. Structural Equation Modeling, 6(1), 1-55. doi:10.1080/10705519909540118

Quintana, S. M. \& Maxwell, S. E. (1999). Implications of recent developments in structural equations modeling for counseling psychology. The Counseling Psychologist, 27, 485-527. doi:10.1177/0011000099274002

Savickas, M. L. (1991). Improving career time perspective. In D. Brown \& L. Brooks (Eds), Techniques of Career Counseling (pp. 236-249). Boston, MA: Allyn \& Bacon.

Savickas, M. L., Silling, S. M., \& Schwartz, S. (1984). Time perspective in vocational maturity and career decision making. Journal of Vocational Behavior, 25, 258-269. doi:10.1016/00018791(84)90049-6

Shell, D. F. (1985). Achievement motivation: Interactive effects of locus of control, expectancy attribution, self-efficacy, goal setting, and future time perspective on academic performance. Unpublished master's thesis, University of Nebraska-Lincoln.

Shell, D. F., \& Husman, J. (2001). The multivariate dimensionality of personal control and future time perspective beliefs in achievement and self-regulation. Contemporary Educational Psychology, 26, 481-506. doi:10.1006/ceps.2000.1073

Shout, P. E., \& Bolger, N. (2002). Mediation in experimental and nonexperimental studies: New procedures and recommendations. Psychological Methods, 7(4), 422-445. doi:10.1037/1082$989 \times 7.4 .422$

Super, D. E. (1980). Life-span, life-space approach to career development. Journal of Vocational Behavior, 16, 282-298. doi:10.1016/0001-8791(80)90056-1 